\title{
Violations of Fundamental Rights in Nigeria during Internal Strife and Civil Disturbances by the Nigerian Security Personnel.
}

\author{
Abubakar S.R. Matazu* \\ Senior Lecturer, Faculty of Law, Usmanu Danfodiyo University, Sokoto, Nigeria
}

\begin{abstract}
Human rights law is the law that deals with the protection of individual and groups against violation by governments of their internationally guaranteed rights and the promotion of these rights. The world is however littered with basic examples of violation of fundamental rights which include, but not limited to discrimination, extra judicial execution, disappearances, torture and unfair trials. This index showcases that the number of human rights abuses are mostly committed by the state agencies, and in Nigeria, by the security personnel, saddled with the responsibility of ensuring protection of lives and properties. This paper therefore addresses instances of those violations during internal strife and civil disturbances in Nigeria
\end{abstract}

Keywords: Civil disturbances, human rights, internal strife, Nigerian security personnel, violation.

\section{Introduction}

Fundamental rights are generally regarded as those aspects of human rights which have been recognized and entrenched under chapter IV of the Nigerian Constitution. They are specifically provided to enhance human dignity and liberty in every modern state. ${ }^{1}$ These rights include; right to life, right to dignity of human person, right to personal liberty, right to fair hearing, right to private and family life, right to freedom of thought, conscience and religion, right to freedom of expression and the press, right to peaceful assembly and association. ${ }^{2}$

Violation of Fundamental rights by Nigeria armed forces in curtailing internal strife and insecurity in Nigeria have been a common occurrence in recent times. Most times, members of the armed forces in Nigeria often come up with a defence that they had the instruction to "shoot at sight". Torture, molestation and extra judicial killings are now a fashion, in flagrant violation of the fundamental human rights of Nigerians. These gruesome acts have not received huge condemnation by the government, who are indirectly encouraging it, since a negligible percentage involved in these violations, were prosecuted and in most cases, the matter was never concluded. These violations will be analyzed under different internal strife in Nigeria.

\section{Specificities of Internal Strife and Civil Disturbances in Nigeria.}

Internal disturbances involve situation where there is no non-international armed conflict, but there exists confrontation within the country, which is charecterised by certain seriousness and duration and which involves act of violence. ${ }^{3}$

The following are however noteworthy as possible consequences and charesteritics of internal tensions, viz;

Mass arrest; large number of persons detained for security reasons; administrative detention for long period; probable ill treatment, torture or material or psychological condition of detention likely to be seriously prejudicial, mental or moral integrity of the detainees; maintaining detainees in communicado for long periods; repressive measures taken against family members or persons having a close relationship with those deprived of their liberty; the suppression of fundamental judicial guarantees, either by the proclamation of a state of emergency or by de facto situations; large scale measures restricting personal freedom, such as relegation, exile assigned residence, displacement; allegation of forced disappearances; increase in the number of acts of violence( such as sequestration and hostage taking) which endanger defenceless persons or spread terror among civilian population. ${ }^{4}$

\footnotetext{
* LL.B Hons, LL.M., PhD, Senior Lecturer, Faculty of Law Usmanu Danfodiyo University, Sokoto.

${ }^{1}$ Falana F., (2004)Fundamental Right Enforcement, (Iqra Books Nigeria, Lagos) p.4

${ }^{2}$ Sections33 to 36, Constitution of the Federal Republic of Nigeria (1999) as amended.

${ }^{3}$ Matazu, A.S.R, (2013) Other Situations of Violence in Nigeria: The Relevance of International Humanitarian Law, in Shehu Abdullahi (Ed), The Footprint of a Judicial Officer (Chattered Graphic Press, Abuja Nigeria) pp330-345

${ }^{4}$ Ibid
} 
It should however be noted that, ICRC on its commentary to article 1(2) of AP II defined internal tension as: Situation of serious tensions (political religious, racial, social economic etc) or sequel of an armed conflict or internal strife...

\subsection{The Ogoni Crisis}

The crisis in Ogoni land and the military crackdown in the land which began in late May 1994, following the murders by a mob of four Ogoni leaders, who were branded as pro-government. In the wake of the murders, which occurred under disputed circumstances, the Rivers State Internal Security Task Force, embarked on a series of punitive raids on Ogoni villages, characterized by flagrant human rights abuses, including extra judicial executions, indiscriminate shooting, arbitrary arrest and detention, floggings, rapes, looting and extortion, which violates Nigeria's obligation under international law and the Nigeria's Constitution. ${ }^{5}$ Testimonies about the Nigerian military's punitive campaign in Ogoni land has been taken from soldiers, who were themselves involved in the violence, as well as from civilian victims. Two Nigerian Soldiers explained to Human Right Watch, their participation in clandestine military raids designed to appear like communal clashes, these testimonies are just part of -a picture that discredits the government's claim that, outbreaks of violence in Ogoni land prior to May 1994 were the result of ethnic strife. ${ }^{6}$ Independent monitoring of the situation in Ogoni land was severely restricted by government since the violence began in 1993 .

Journalists and others who have tried to visit the area without military escort have been arrested and sometimes deported, thereby violating their fundamental rights, ${ }^{7}$ of freedom of movement and that of expression.

\subsection{Boko Haram Crisis}

The Boko Haram sect which was established and well grounded in Borno State has been carrying out its religions activities in the state before it eventually went violent. The extrajudicial killing of the sect leader, Muhammad Yusuf, by the Nigerian Police in 2009, led to the more violent activities of the sect. In 2009, soldiers arrested Muhammad Yusuf and credible media reports claimed that police executed Yusuf, whose bruised body subsequently was seen at State Police Headquarter with multiple bullet wounds. Police had initially admitted killing Yusuf in custody, but they subsequently claimed that, he died while trying to escape. Buji Fai, a former state government official suspected of funding Boko Haram, also reportedly died in custody. Ever since, no day passes without news of shootings, bomb blast, kidnappings, gun battles and violent confrontations between Nigeria's Security Forces and the members of Boko Haram sect. This resulted in enormous loss of lives and properties, internal displacements and massive violations of human rights.

A counter terrorism Unit, named Joint Task Force (JTF) and the Special Task Force (STF) comprising of the Nigerian Army, Air force, Navy, Police, Immigrations, Customs, State Security Services and the Defence Intelligent Agency were constituted to take over security management and help restore order in the violent - ridden states. Under this arrangement, security operatives were empowered to make arrests without proof, and conduct searches without warrants, including demolishing of house, on security grounds.

Consequently, pulling and burning down of houses and private residences, suspected to be owned or occupied by members of the group, becomes notably rampant in the North and especially the North Eastern States of the country, where attacks have snowballed into catastrophic proportions. ${ }^{8}$ Families, who lose their homes, to punitive demolitions, were not given the right to rebuild their homes, even after an error of the demolishing act has been established. ${ }^{9}$ The mere suspicion of harboring the sect members, has consistently been used to justify arson and the habitual burning of private residences, properties and businesses of citizens. ${ }^{10}$

Across the Northern states of Borno, Kano, Plateau and Yobe, buildings where Improvised Explosive Devices (IEDs) and other dangerous weapons were allegedly found, have been demolished, following violent military raids. These types of demolitions are generally extremely violent, bloody, unplanned and carried out with utmost disregard for the due process of law and the human rights of the occupiers, regardless of their status, as indigenous people. The demolitions happen instantaneously, without prior warning and often during the night hours, giving inhabitants little or no time to evacuate their properties. No particular procedure is followed to determine the actual owners of the buildings or to establish the complicity of such house owners in terrorist activities.

These types of demolitions have curiously, and unjustifiably, justified attacks on women, children and youths across the volatile states. Nearly all reported incidents of anti-insurgency based house demolitions, are

\footnotetext{
${ }^{5}$ Human Right Watch, The Ogoni Crisis: A Case study of Military Repression in Southeastern Nigeria, 1 July, 1995 available at: http://www.LHihcr.org/refworld /docid/3ae6a7d8c.html, visited last 20 November, 2013

${ }_{6} \frac{\mathrm{Ibid}}{\mathrm{Ibid}}$

${ }^{7}$ See Section 39, Constitution of the Federal Republic of Nigeria, 1999.

${ }^{8}$ Available at http://www.africanheraldexpress.com/blog7/2012/30/demolished, visited last 30 July, 2012

7 Section 43, Nigerian Constitution

${ }^{10}$ African Herald, op cit
} 
accompanied by the unlawful arrest and detention of these categories of people, transcends to a veiled policy of substituting fleeing crime suspects with their family members and wives. ${ }^{11}$ Arresting relatives of fleeing suspect is totally wrong and constitutes a flagrant breach of fundamental human rights of the arrested persons.

The absence of initiatives and mechanisms for weighing the human rights effects of security measures in terms of proportionality and necessity is also compounding the crisis. This is because the intensity of the bloodshed and killings, have succeeded in scaring away the media, the civil society and other independent watchdogs' interventions from reaching the conflict areas, the high handedness and human rights violations associated with both the heavy militarization of these States, remains largely undocumented, unreported and undeclared. Not only that, security force are usually unwilling to release, classified information and micro-level data on terror attacks and counter - terrorism operations, as would enable independent evaluation of the effects. This, has severely hindered attempts to comprehensively evaluate the extent of the violations of fundamental rights during these crises. At present, North East Nigeria is the most dangerous place in the world to be a youth, especially a male teen. From Borno, to Kano, Jos and Bauchi, young people have been disproportionately targeted with violence by the Nigerian Armed Forces. Slum neighborhoods and other areas with very high concentration of youth populations are often criminalized, and on that basis, raided repeatedly under the cover of manhunt exercises, for Boko Haram members. Frequent house to house searches conducted without warrants, often serve as prelude to demolition exercises, followed by indiscriminate arrest and shootings of young people who are often made to lie down before the shootings. Handicaps and baggers were not left out in these shooting by members of the Nigerian armed force.

The summary of the activities of the Nigerian arm forces in this part of Nigeria showcases the fact that, they are lacking in training and no respect is had, whatsoever, for human race, as well as, rule of engagement, if there is any.

\subsection{Occupy Nigeria Crisis Demonstrations}

On the 1st of January, 2012 the Nigerian government unilaterally increased the pump price, by removing the so called "subsidy" on petroleum products. This led to strike action by the Nigerian Labour Congress (NLC), Trade Union Congress of Nigeria (TUC) as well as other trade unions.

Peaceful protest was carried out by millions of Nigerians, across the country, to ventilate their displeasure over the petroleum products' price hike.

In Lagos, the Save Nigerian Group and its allies organized a peaceful protest by converging at the Gani Fawehinmi Park, Ojota and Silver Jubilee roundabout in Kano. Five days into the peaceful protests, Nigeria's President, Goodluck Jonathan, deployed soldiers around the city of Lagos, who forcefully dispersed protesters throughout Nigeria. Several protesters were dispersed by heavily armed soldiers, shooting sporadically, live bullets, leading to mayhem as the protesters scampered for safety. Several protesters marched on Lagos streets in defiance of earlier orders by the government to prevent further protests. ${ }^{12}$ Soldiers flooded the street, dismantling public address system put in place by the Save Nigeria Group, at the Population, Square named after the late Lagos lawyer, Gani Fawehinmi. Police fired tear gas and beat up protesters to force them out of the Gani Fawehinmi Square.

Human rights lawyer, Femi Falana told Sahara Reporters that, soldiers prevented him from reaching the venue of the scheduled rally at the Park. He was refused access, despite protests that the military violates his rights, by preventing him from reaching the venue ${ }^{13}$ thereby violating his fundamental right. ${ }^{14}$

However, defiant group of protesters led by prominent activists, Bamidele Aturu and Abiodun Areme of the Joint Action Front (JAF), defied the soldiers and marched on Ikorodu road, until armed soldiers dispersed the crowd by shooting recklessly. About 16 check points and barricades were mounted around the Gani Fawehinmi Park.

In Kano, the protesters who had occupied the Silver Jubilee Square, where the protesters named Liberation Square were violently dispersed by the Police using tear gas. ${ }^{15}$ The Nigerian Police, in concert with members of a vigilante group

applied maximum force to disperse thousands of protesters, occupying the Square. Eye witness told vanguard newspaper that the Police fired several canisters of tear gas at the sleeping crowd, before unleashing violence on the protesters. In the ensuing confusion, no fewer than 42 protesters sustained various degree of injury, while six were arrested and subsequently released on intervention by leaders of the protesters. ${ }^{16}$

\footnotetext{
${ }^{11}$ Ibid

${ }^{12} \mathrm{http} / / /$ mobile.saharareporters.com/news-page/soldiers-shot-dispers-occupy-protersters-lagos-nigerian-secret-police-raids-cnnsoffice, visited last 28 November, 2013

13 . Ibid

14 Section 40, Nigerian Constitution.

15 , http://www.africa.no/detailed/21070html/vanguard, visited last 6 January, 2012

16 Ibid.
} 
In Ilorin, the Kwara state capital, one of the protesters, Muyideen Mustapha was shot dead by the Nigerian police in an effort to disperse the protesters on the $5^{\text {th }}$ of January, 2012 while eight others were arrested and detained. ${ }^{17}$

In Ado Ekiti, it was a joint square of armed Mobile Police and officers of the State Security Service (SSS) that dispersed protesters who were gathering on Thursday morning, $5^{\text {th }}$ January, 2012 to kick off protest. ${ }^{18}$ The unleashment of soldiers on unarmed and peaceful protesters who were merely demanding accountability and transparency from their leaders is a violation of the fundamental rights of association contrary to the provisions of the Constitution of the Federal Republic of Nigeria, 1999, under sections 34, 40 and 41, respectively. It is worthy of note that, these provisions are in respect of right to dignity of human person, right to peaceful assembly and association and right to freedom of movement.

It was on this note that Nobel Laureate, Wole Soyinka has this to say on the action of the president of Nigeria:

The president sent in the army and shock police squads to forcibly seize and occupy grounds from a demonstrating public, a violation of the people's right as it happens, that has been further consolidated by a pronouncement of the Courts of law. This should be seen as a grave danger to democracy, and a warning both the participants and those who like myself...though unable to be present, lent both vocal and moral support to the demonstration, have been maligned and insulted by such reductionist reasoning. ${ }^{19}$

\subsection{Jos Crisis}

The crisis in Jos which started almost 2 decade ago became heightened in 2008 between the indigenes and the Hausa settlers.

The indigenes tribes- Afizere, Anaguta and Bero are predominantly Christians, while the Hausa settlers, are predominantly Muslims.

The crisis, between the two groups, over the years, has erupted into violent clashes claiming thousands of lives. The story of the 2008 outbreak is told against its backgrounds of ethnicity, religion, local history, local politics and most harmfully, corrupt and incompetent government. During this crisis, the presence of members of the Nigerian armed forces, added salt to an open injury, since they have recklessly violated the fundamental rights of citizens. What charecterised their stay there were; massive arrests, ill treatment and extra judicial execution. These arrests, ill-treatments and killings include young children, some in their teens and women. There were also reports of police shooting people who were not armed or engaged in any criminal acts. For example, three men who were sitting outside their house on September 9, 2001 were shot by policemen, with various degrees of injury. ${ }^{20}$ Human Right Watch interviewed two of them who had been injured, one of whom was still in the hosp ital ${ }^{21}$

In July, 2012, following the death of a Senator and a Member of the Plateau State House of Assembly, reports indicate that the Joint Task Force (JTF), whose action was responsible for the escalation of the recent crisis, destroyed Fulani settlement in Barkin Ladi and Riyom Local Government areas, particularly Luggere, a Fulani stronghold, was destroyed, by the Joint Task Force, and its inhabitants, forcefully dispersed. ${ }^{22}$

\subsection{Port Harcourt Demolitions}

In 2010, AI released the report; Port Harcourt Demolitions: Excessive use of force against demonstrators. In 2009 Nigerian police and Joint Task Force (JTF) fired into the crowd of citizens, peacefully protesting the proposed demolition of their homes. The report stated that the JTF shot and seriously injured at least 12 persons, and witnesses claimed that they saw six bodies in a police vehicle. ${ }^{23}$ Authorities had neither charged nor punished anyone for the killings done in violation of the fundamental right to own immovable property and to conduct peaceful protest.

The above could not be the only instances of Nigerian armed forces highhandedness. There are many untold stories and these will continue, for God knows how long, since the society appreciates and condones culture of impunity.

\footnotetext{
17 http:llt.co/EvsW17ud

${ }_{18}^{18}$.Ogada, World Press.com.

${ }^{19}$ Available at sunnewsonline./com/... ./Soyinka - replies -Jonathan on fuel subsidy protest, http://twiter.com/sunnewsnigeria, visited last 28 November, 2013

${ }^{20}$ Human Rights Watch Interview Jos Prison, October 1, 2001, available at www.hrw.org/.../nigeria1201-04

${ }^{21}$ Ibid

${ }^{22}$ Available at disclosure.blogspot.co.uk/20I2/07/disclosure 348-fulani and genocide-dream.html, visited last 28 November, 2013

${ }^{23}$ Jos Civil Disturbances Commission of Inquiry report, available at https://twiter.com/sahara reporters/... visited last 27 November, 2013
} 


\section{Conclusion}

Every society or a nation state which condones the ineptitude of its security personnel by allowing it to commit a lot of atrocities, due to lack of respect to the rule of engagement, the culture of impunity, will forever remain the order of the day. That society will always lag behind the civilized nations and thus, attract condemnation.

Internal strife and insecurity in Nigeria has become a constant phenomenon which mostly is as a result of government policies which tend to affect the masses negatively thereby leading to peaceful protest, demonstrations and violence. The Nigerian government, in an attempt to curb the ensuing violence, often use members of the armed forces who resort to grave violation of fundamental rights with reckless abandon leading to chaos and injustice in the country and making the provisions of the constitution protecting fundamental right of citizen a mere theory with difficulties in application.

\section{References}

[1]. Falana F., (2004)Fundamental Right Enforcement, (Iqra Books Nigeria, Lagos) p.4

[2]. Constitution of the Federal Republic of Nigeria (1999) as amended.

[3]. Matazu, A.S.R, (2013) Other Situations of Violence in Nigeria: The Relevance of International Humanitarian Law, in Shehu A.,(Ed), The Footprint of a Judicial Officer (Chattered Graphic Press, Abuja Nigeria) pp330-345

[4]. Human Right Watch, The Ogoni Crisis: A Case study of Military Repression in Southeastern Nigeria, 1 July, 1995 available at: http://www.LHihcr.org/refworld /docid/3ae6a7d8c.html, visited last 20 November, 2013

[5]. http://www.africanheraldexpress.com/blog7/2012/30/demolished, visited last 30 July, 2012

[6]. African Herald

[7]. http://mobile.saharareporters.com/news-page/soldiers-shot-dispers-occupy-protersters-lagos-nigerian-secret-police-raids-cnnsoffice, visited last 28 November, 2013

[8]. http://www.africa.no/detailed/21070html/vanguard, visited last 6 January, 2012

[9]. http:1lt.co/EvsW17ud

[10]. Ogada, World Press.com.

[11]. sunnewsonline./com/... ./Soyinka - replies -Jonathan on fuel subsidy protest, http://twiter.com/sunnewsnigeria, visited last 28 November, 2013

[12]. Human Rights Watch Interview Jos Prison, October 1, 2001, available at www.hrw.org/.../nigeria1201-04

[13]. disclosure.blogspot.co.uk/20I2/07/disclosure 348-fulani and genocide-dream.html, visited last 28 November, 2013

[14]. Jos Civil Disturbances Commission of Inquiry report, available at https://twiter.com/sahara reporters/...visited last 27 November, 2013 